ORP-53909 -FP

Revision 0

\title{
IMPACT OF PARTICLE AGGLOMERATION ON ACCUMULATION RATES IN THE GLASS DISCHARGE RISER OF HLW MELTER
}

Prepared for the U.S. Department of Energy

Assistant Secretary for Environmental Management

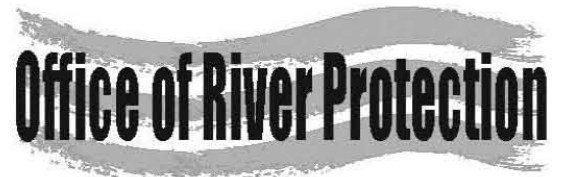

P.O. Box 450

Richland, Washington 99352 
ORP-53909 -FP

Revision 0

\section{IMPACT OF PARTICLE AGGLOMERATION ON ACCUMULATION RATES IN THE GLASS DISCHARGE RISER OF HLW MELTER}

A. A. Kruger

Department of Energy - Office of River Protection

C. A. Rodriguez

Pacific Northwest National Laboratory

J. Matyas

Pacific Northwest National Laboratory
A. T. Owen
Pacific Northwest National Laboratory
D. P. Jansik
Pacific Northwest National Laboratory
J. B. Lang
Pacific Northwest National Laboratory

Date Published

November 2012

To be Presented at

MS\&T'12

American Ceramic Society

Pittsburgh, PA

$11 / 01 / 2012$

Published in

Ceramic Transactions

Prepared for the U.S. Department of Energy

Assistant Secretary for Environmental Management

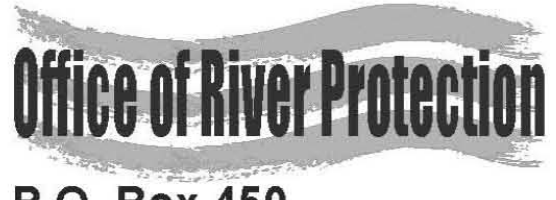

P.O. Box 450

Richland, Washington 99352

Copyright License

By acceptance of this article, the publisher and/or recipient acknowledges the U.S. Government's right to retain a non exclusive, royalty-free license in an to any copyright covering this paper. 
ORP-53909 -FP

Revision 0

\section{LEGAL DISCLAIMER}

This report was prepared as an account of work sponsored by an agency of the United States Government. Neither the United States Government nor any agency thereof, nor any of their employees, makes any warranty, express or implied, or assumes any legal liability or responsibility for the accuracy, completeness, or any third party's use or the results of such use of any information, apparatus, product, or process disclosed, or represents that its use would not infringe privately owned rights. Reference herin to any specific commercial product, process, or service by trade name, trademark, manufacturer, or otherwise, does not necessarily constitute or imply its endorsement, recommendation, or favoring by the Unites States

Government or any agency thereof or its contractors or subcontractors. The views and opinions of authors expressed herein do not necessarily state or reflect those of the United States Government or any agency thereof.

This report has been reproduced from the best available copy.

Printed in the United States of America 


\author{
J. Matyáś ${ }^{1}$, D. P. Jansik ${ }^{1}$, A. T. Owen ${ }^{1}$, C.A. Rodriguez ${ }^{1}$, J. B. Lang ${ }^{1}$, A.A. Kruger ${ }^{2}$ \\ 1. Pacific Northwest National Laboratory \\ Richland, WA, USA \\ 2. Office of River Protection \\ Richland, WA, USA
}

\title{
ABSTRACT
}

The major factor limiting waste loading in continuous high-level radioactive waste (HLW) melters is an accumulation of particles in the glass discharge riser during a frequent and periodic idling of more than 20 days. An excessive accumulation can produce robust layers a few centimeters thick, which may clog the riser, preventing molten glass from being poured into canisters. Since the accumulation rate is driven by the size of particles we investigated with Xray microtomography, scanning electron microscopy, and image analysis the impact of spinel forming components, noble metals, and alumina on the size, concentration, and spatial distribution of particles, and on the accumulation rate. Increased concentrations of $\mathrm{Fe}$ and $\mathrm{Ni}$ in the baseline glass resulted in the formation of large agglomerates that grew over the time to an average size of $\sim 185 \pm 155 \mu \mathrm{m}$, and produced $>3 \mathrm{~mm}$ thick layer after $120 \mathrm{~h}$ at $850{ }^{\circ} \mathrm{C}$. The noble metals decreased the particle size, and therefore significantly slowed down the accumulation rate. Addition of alumina resulted in the formation of a network of spinel dendrites which prevented accumulation of particles into compact layers.

\section{INTRODUCTION}

The most common and potentially problematic solids that can form and accumulate in joule heated melters vitrifying high-level radioactive waste (HLW) are spinel crystals $\left[(\mathrm{Fe}, \mathrm{Ni}, \mathrm{Mn}, \mathrm{Zn})(\mathrm{Fe}, \mathrm{Cr})_{2} \mathrm{O}_{4}\right], \mathrm{RuO}_{2}$, and their combination. There is a worry that these solids can growth into large particles or form large agglomerates in the glass discharge riser of the melter during a frequent and periodic idling from 20 to 100 days ${ }^{1,2}$ when the temperature of the molten glass can drop in some areas to as low as $850^{\circ} \mathrm{C}$. This, together with the stagnant melts and small inner diameter of the riser $(\sim 76 \mathrm{~mm})$, provide ideal conditions for accumulation of particles/agglomerates into a few centimeters thick robust layer ${ }^{3}$, which may clog the riser and thereby prevent molten glass from being poured into canisters.

A question arises whether it would be possible to control the accumulation rate of spinel crystals through optimization of noble metals concentration in radioactive wastes. A small concentration of noble metals may be sufficient to nucleate enough spinel crystals to limit their growth to a size of $10 \mu \mathrm{m}$ or less. However, high concentrations of noble metals are not favorable because of their tendency to form large agglomerates ${ }^{4}$. These rapidly settling agglomerates can also form due to interactions of spinel crystals with noble metal particles. ${ }^{5}$ Another factor that can greatly affect the accumulation of spinel crystals in glasses containing high concentrations of spinel forming components is an addition of $\mathrm{Al}_{2} \mathrm{O}_{3}$ or $\mathrm{Li}_{2} \mathrm{O}$. These components tend to promote the formation of a network of large spinel dendrites which prevents building the dense settled layers. ${ }^{5}$

This laboratory study investigated particle agglomeration (size, concentration of agglomerates and their spatial distribution) and accumulation rates in three HLW glass 
compositions with X-ray microtomography (XMT), scanning electron microscopy (SEM), and image analysis. Also, an attempt was made to measure an average composition of spinel crystals from elemental dot maps that were produced with an energy dispersive spectroscopy (EDS).

\section{EXPERIMENTAL}

\section{HLW Glass Compositions}

Table I shows compositions for three glasses (Ni1.5/A110, Ni1.5/Fe17.5, and $\mathrm{Ni1.5} / \mathrm{Fe} 17.5 / \mathrm{Ru} 0.015)$ used in the particle agglomeration study. The varied components were $\mathrm{Al}_{2} \mathrm{O}_{3}, \mathrm{Fe}_{2} \mathrm{O}_{3}, \mathrm{NiO}$, and $\mathrm{RuO}_{2} / \mathrm{Rh}_{2} \mathrm{O}_{3}$. The remaining components were kept in the same proportions as in the baseline glass. ${ }^{3}$ Glass batches were prepared from AZ-101 simulant and additives $\left(\mathrm{H}_{3} \mathrm{BO}_{3}, \mathrm{Li}_{2} \mathrm{CO}_{3}, \mathrm{Na}_{2} \mathrm{CO}_{3}\right.$, and $\left.\mathrm{SiO}_{2}\right)$. Additional $\mathrm{Al}, \mathrm{Fe}, \mathrm{Ni}$, and $\mathrm{Rh}$ were added as $\mathrm{Al}_{2} \mathrm{O}_{3}, \mathrm{Fe}_{2} \mathrm{O}_{3}, \mathrm{NiO}$, and $\mathrm{Rh}_{2} \mathrm{O}_{3}$. Ruthenium was added in the form of ruthenium nitrosyl nitrate solution drop by drop to $\mathrm{SiO}_{2}$ that was dispersed on a Petri dish. The $\mathrm{SiO}_{2}$ cake was dried in oven at $105^{\circ} \mathrm{C}$ for 1 hour, quenched, and hand-mixed in the plastic bag with the rest of the glass batch. Then, the glass batch was milled in an agate mill for $5 \mathrm{~min}$ to ensure homogeneity. Glasses were produced in Pt-10\%Rh crucibles following a two-step melting process: melting of homogenized glass batches at $1200^{\circ} \mathrm{C}$ for $1 \mathrm{~h}$ and remelting of produced glasses at the same temperature and time after quenching and grinding.

Table I. Composition of glasses in mass fraction of oxides and halogens.

\begin{tabular}{|c|c|c|c|c|}
\hline Component & $\mathrm{BL}$ & Ni1.5/Al10 & Ni1.5/Fe17.5 & $\mathrm{Ni1} .5 / \mathrm{Fe} 17.5 / \mathrm{Ru} 0.015^{(\mathrm{a})}$ \\
\hline $\mathrm{Al}_{2} \mathrm{O}_{3}$ & 0.0821 & 0.1000 & 0.0784 & 0.0783 \\
\hline $\mathrm{B}_{2} \mathrm{O}_{3}$ & 0.0799 & 0.0776 & 0.0763 & 0.0762 \\
\hline $\mathrm{BaO}$ & 0.0009 & 0.0009 & 0.0009 & 0.0009 \\
\hline $\mathrm{CaO}$ & 0.0057 & 0.0055 & 0.0054 & 0.0054 \\
\hline $\mathrm{CdO}$ & 0.0065 & 0.0063 & 0.0062 & 0.0062 \\
\hline $\mathrm{Cr}_{2} \mathrm{O}_{3}$ & 0.0017 & 0.0017 & 0.0016 & 0.0016 \\
\hline $\mathrm{F}$ & 0.0001 & 0.0001 & 0.0001 & 0.0001 \\
\hline $\mathrm{Fe}_{2} \mathrm{O}_{3}$ & 0.1451 & 0.1409 & 0.1750 & 0.1750 \\
\hline $\mathrm{K}_{2} \mathrm{O}$ & 0.0034 & 0.0033 & 0.0032 & 0.0032 \\
\hline $\mathrm{Li}_{2} \mathrm{O}$ & 0.0199 & 0.0193 & 0.0190 & 0.0190 \\
\hline $\mathrm{MgO}$ & 0.0013 & 0.0013 & 0.0012 & 0.0012 \\
\hline $\mathrm{MnO}$ & 0.0035 & 0.0034 & 0.0033 & 0.0033 \\
\hline $\mathrm{Na}_{2} \mathrm{O}$ & 0.1866 & 0.1812 & 0.1781 & 0.1780 \\
\hline $\mathrm{NiO}$ & 0.0064 & 0.0150 & 0.0150 & 0.0150 \\
\hline $\mathrm{P}_{2} \mathrm{O}_{5}$ & 0.0032 & 0.0031 & 0.0031 & 0.0031 \\
\hline $\mathrm{SiO}_{2}$ & 0.4031 & 0.3913 & 0.3848 & 0.3846 \\
\hline $\mathrm{SO}_{3}$ & 0.0008 & 0.0008 & 0.0008 & 0.0008 \\
\hline $\mathrm{TiO}_{2}$ & 0.0003 & 0.0003 & 0.0003 & 0.0003 \\
\hline $\mathrm{ZnO}$ & 0.0002 & 0.0002 & 0.0002 & 0.0002 \\
\hline $\mathrm{ZrO}_{2}$ & 0.0416 & 0.0404 & 0.0397 & 0.0397 \\
\hline $\mathrm{Cl}$ & 0.0002 & 0.0002 & 0.0002 & 0.0002 \\
\hline $\mathrm{Ce}_{2} \mathrm{O}_{3}$ & 0.0020 & 0.0019 & 0.0019 & 0.0019 \\
\hline $\mathrm{CoO}$ & 0.0001 & 0.0001 & 0.0001 & 0.0001 \\
\hline $\mathrm{CuO}$ & 0.0004 & 0.0004 & 0.0004 & 0.0004 \\
\hline $\mathrm{La}_{2} \mathrm{O}_{3}$ & 0.0022 & 0.0021 & 0.0021 & 0.0021 \\
\hline $\mathrm{Nd}_{2} \mathrm{O}_{3}$ & 0.0018 & 0.0017 & 0.0017 & 0.0017 \\
\hline $\mathrm{SnO}_{2}$ & 0.0010 & 0.0010 & 0.0010 & 0.0010 \\
\hline Total & 1.0000 & 1.0000 & 1.0000 & 1.0000 \\
\hline
\end{tabular}




\section{Particle Agglomeration}

Figure 1 shows the testing assembly for the lab-scale study of the particle agglomeration. The assembly consisted of an alumina crucible with an outer and inner diameter of 18 and $15 \mathrm{~mm}$, respectively, and height $80 \mathrm{~mm}$ that was positioned on the alumina plate inside a Ptcrucible with an inner diameter of $30 \mathrm{~mm}$ and height $100 \mathrm{~mm}$. The fabricated glasses were first melted in $\mathrm{Pt} / 10 \% \mathrm{Rh}$ crucibles at $1200^{\circ} \mathrm{C}$ for an hour, and then the crucibles were removed one by one from the melting furnace, and molten glass poured into each of four assemblies that were rested on the 508-mm-diameter platform inside the big Deltech furnace at $850^{\circ} \mathrm{C}$. These assemblies were covered with a lid and removed (air-quenched) at different times up to 5 days. The alumina crucibles were core-drilled from assemblies and were investigated with XMT for the size and distribution of agglomerates. Then, the thin sections were prepared from middle of the crucible for optical microscopy and SEM-EDS observations, and an image analysis.



Figure 1. Cross-section of testing assembly.

\section{X-ray Microtomography}

XMT analysis was conducted using an NSI X-View Digital X-ray Imaging and Microfocus Computed Tomography (XMCT) system (North Star Imaging Inc., Rogers, Minnesota). X-rays were generated by a microfocus X-ray source (Comet Feinfocus model $160.48160 \mathrm{kV}$ ) and collected by a PaxScan ${ }^{\circledR} 2520 \mathrm{~V}$ flat panel digital X-ray detector with an active imaging area of $203 \times 254 \mathrm{~mm}$. This system is capable of spatial resolution of $6 \mu \mathrm{m}$ in the focal plane for an object $\sim 6 \mathrm{~mm}$ in diameter. Data acquisition and image reconstruction were conducted with X-View IW and efX-ct software's (North Star Imaging Inc., Rogers, Minnesota), respectively.

The X-ray tube voltage and current were adjusted to $110 \mathrm{kV}$ and $340 \mu \mathrm{A}$, respectively, to produce an optimal luminosity contrast with values between 3500 and 6500. An X-ray detector response was optimized with dark and light field calibrations (gain or wedge), which were performed with the crucible removed from the field of view to create a uniform background response. The core-drilled alumina crucibles were put in the middle of the rotating stage that was positioned $89.8 \mathrm{~mm}$ from the center axis of rotation and X-ray tube, which resulted in a resolution of $18.7 \mu \mathrm{m}$ (the smallest particle that can be detected). Each crucible was imaged in three separate sections (bottom, middle, and top) at 1 frame per second, with two images collected per $0.25^{\circ}$ of rotation over $360^{\circ}$. Subsequently, the off-set calibration of stage with a 
medium sized NSI calibration tool was performed on each section to correct stage movement errors, and images were reconstructed with efX-ct software.

Two-dimensional (XY) slice reconstructions of the bottom, middle, and top sections of the crucible were segmented with AVIZO Fire $7.0^{\circledR}$ image processing software (Visualization Science Group, Burlington, MA) to capture location and shape of particles. The size and count of particles was quantified with a three-dimensional volume quantification algorithm. The data were exported into Matlab, where each crucible volume was sectioned into $32 \mathrm{x} 2.5$-mm tall cylinders to obtain size, count, and volume faction of particles as a function of distance from the bottom of the crucible.

Scanning Electron Microscopy and Image Analysis

The YZ thin-sections of entire crucibles were polished, carbon coated and analyzed with JEOL JSM-5900 SEM (SEMTech Solutions Inc., North Billerica, Massachusetts). The operating conditions were $15 \mathrm{kV}$ acceleration voltage and working distance $34 \mathrm{~mm}$. SEM images of

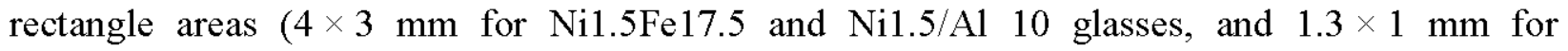
Ni1.5Fe17.5/Ru0.015 glass) were centered along z-axis and were taken every $5 \mathrm{~mm}$ starting from the bottom and moving up to the top of the crucible. Clemex Vision PE 6.0 image analysis software (Clemex Technologies Inc., Québec, Canada) was used to analyze the images for the size and surface area fraction of particles.

Energy-Dispersive X-ray Spectroscopy for Composition Analysis

Elemental dot maps were collected with a SEM JEOL 7001F/TTLS (JEOL Ltd., Tokyo, Japan) equipped with an Energy-Dispersive X-ray Spectroscopy (EDS) silicon drift detector (SDD, 30mm active area). The microscope was setup at working distance of $10 \mathrm{~mm}$ at an accelerating voltage of $15 \mathrm{kV}$ and probe current of 2-10 $\mu \mathrm{A}$. The SDD peaking time was between $0.8-3.2 \mu$ s to maintain a count rate of $150-200 \mathrm{kcps}$ and a dead time of $30-50 \%$. Maps were collected in a drift corrected mode with a resolution of $1024 \times 800$ pixels, $200 \mu \mathrm{s} / \mathrm{pixel}$, and copulation of 256 frames.

\section{RESULTS AND DISCUSSION}

Figure 1 shows the spatial distribution of spinel crystals, air voids, and cracks in the twodimensional XMT cross-sections for Ni1.5/Fe17.5 glass heat-treated at $850{ }^{\circ} \mathrm{C}$ for $96 \mathrm{~h}$. These cross-sections are for the box with dimensions of $30 \times 7 \times 7 \mathrm{~mm}$ which was extracted from the center of the bottom section of the crucible. The $y-z$ plane visualizes projection of all crystals onto one plane. The high concentration of nickel and iron in the glass resulted in the formation of large spinel crystals/agglomerates with an average size $>100 \mu \mathrm{m}$. These sparsely-distributed particles rapidly settled and accumulated in $>3 \mathrm{~mm}$ thick layer.

Figure $2 \mathrm{~A}$ and $\mathrm{B}$ show the size and volume distribution of particles for the entire crucible in the Ni1.5/Fe17.5 glass heat-treated at $850^{\circ} \mathrm{C}$ for 24 and $96 \mathrm{~h}$. The low grey-level contrast of XMT in the layer $(96 \mathrm{~h})$ resulted in an overestimation of the particle size $(>450 \mu \mathrm{m})$ and occupied volume $(>86 \%)$. The image analysis was not able to correctly resolve the individual particles but clumped them together into big clusters. The size of particles and their volume distribution was quite uniform after $24 \mathrm{~h}$ up to $10 \mathrm{~mm}$ below the glass level, and ranged from 100 to $130 \mu \mathrm{m}$ and $1-2$ vol $\%$, respectively. In contrast, particles of an average size $\sim 185 \pm 155 \mu \mathrm{m}$ were identified in the $30-\mathrm{mm}$ region above the bottom after an additional $72 \mathrm{~h}$ of settling. This indicates that the particles grew as they settled with a rate $\sim 1.1 \mu \mathrm{m} / \mathrm{h}$. 




Figure 1. X-ray microtomography cross-sections for Ni1.5/Fe1 7.5 glass $\left(850^{\circ} \mathrm{C}-96 \mathrm{~h}\right)$; glass is blue and gray, spinel crystals are yellow, cracks and air voids are white. All the crystals are projected onto $\mathrm{y}-\mathrm{z}$ plane.

A

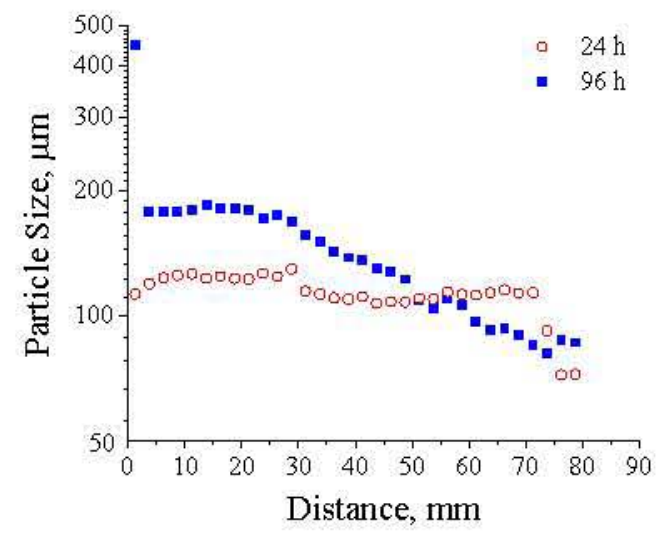

$\mathrm{B}$

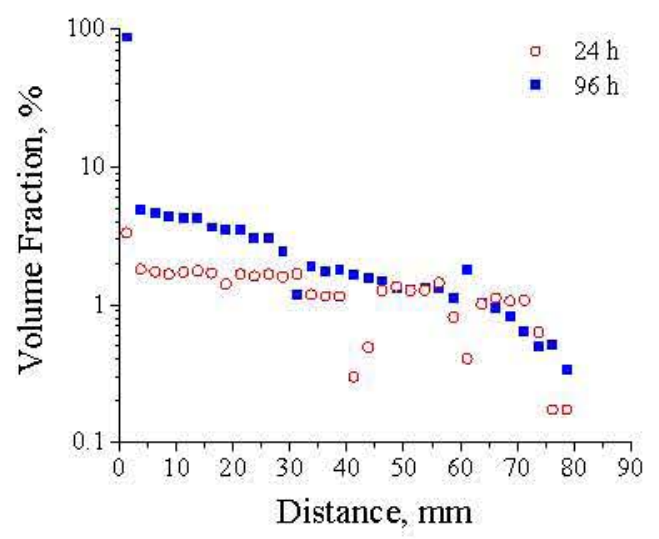

Figure 2. Size (A) and volume distribution (B) of particles vs. distance from the bottom of the crucible ( $0 \mathrm{~mm}$ - bottom, $80 \mathrm{~mm}$ - top) for Nil.5/Fe17.5 glass $\left(850^{\circ} \mathrm{C}\right.$ for 24 and $\left.96 \mathrm{~h}\right)$.

Table II shows the distribution of particle sizes as determined with image analysis from SEM images for Ni1.5/Fe17.5, Ni1.5/Fe17.5/Ru0.015, and Ni1.5/Al10 glasses. Figure 3 shows the surface area occupied by the particles as a function of distance from the bottom of the crucible for the same glasses. Addition of Ni and Fe to baseline glass resulted in the formation of large particles that grew over the time, e.g., $90 \%$ of all particles were smaller than $85 \pm 56$ and $126 \pm 111 \mu \mathrm{m}$ after 24 and $96 \mathrm{~h}$, respectively. These large particles were initially uniformly distributed throughout the sample but got concentrated in $\sim 25-\mathrm{mm}$ region at the bottom after 49 and $96 \mathrm{~h}$. The settling of particles within this region produced compact 0.5 - and 3-mm-thick layers with particles covering $\sim 34 \%$ of area, respectively. Figure 4 visualizes the layers accumulated in Ni1.5/Fe17.5 glass after 49 and $96 \mathrm{~h}$ at $850^{\circ} \mathrm{C}$. In contrast, addition of noble metals to high-Ni-Fe glass resulted in the uniform distribution of particles with a size below $30 \mu \mathrm{m}$ (D90) even after $120 \mathrm{~h}$ at $850^{\circ} \mathrm{C}$. Because of the smaller particles the accumulated layers were only 79 and $168 \mu \mathrm{m}$ thick after 72 and $120 \mathrm{~h}$, respectively. Figure 5 shows the layers accumulated in Ni1.5/Fe17.5/Ru0.015 glass after 72 and $120 \mathrm{~h}$ at $850^{\circ} \mathrm{C}$. Addition of $\mathrm{Al}$ to 
high-Ni glass produced a network of spinel dendrites with "arms" as long as $1 \mathrm{~mm}$. These dendrite locked structure prevented accumulation of particles into thick layer. The dendrites slowly grew (see Table II) and dendritic network got more compacted over the time $(\sim 1 \%$ after $24 \mathrm{~h}$ vs. $\sim 3 \%$ after $72 \mathrm{~h}$ ). Figure 6 shows an example of the 3D network of spinel dendrites that formed in high-Ni-Al glass after $72 \mathrm{~h}$ at $850^{\circ} \mathrm{C}$. Figure 7 shows thin sections of dendrites for the same glass heat-treated at $850^{\circ} \mathrm{C}$ for 24 and $72 \mathrm{~h}$.

Table II. Distribution of particle sizes for Ni1.5/Fe17.5, Ni1.5/Fe17.5/Ru0.015, and Ni1.5/Al10 glasses heat-treated at $850^{\circ} \mathrm{C}$ for different times; D10, D50, and D90-10, 50, 90\% of crystals are smaller than these values, respectively.

\begin{tabular}{|c|c|c|c|c|}
\hline Glass & Time, $\mathrm{h}$ & $\mathrm{D} 10, \mu \mathrm{m}$ & $\mathrm{D} 50, \mu \mathrm{m}$ & $\mathrm{D} 90, \mu \mathrm{m}$ \\
\hline \multirow{2}{*}{$\mathrm{Ni1.5/Fe17.5}$} & 24 & $27 \pm 22$ & $51 \pm 36$ & $85 \pm 56$ \\
\cline { 2 - 5 } & 96 & $41 \pm 48$ & $74 \pm 64$ & $126 \pm 111$ \\
\hline \multirow{3}{*}{$\mathrm{Ni1.5/Fe17.5/Ru0.015}$} & 72 & $9 \pm 6$ & $21 \pm 9$ & $28 \pm 10$ \\
\cline { 2 - 5 } & 96 & $12 \pm 6$ & $20 \pm 9$ & $27 \pm 10$ \\
\cline { 2 - 5 } & 120 & $12 \pm 8$ & $21 \pm 8$ & $29 \pm 13$ \\
\hline \multirow{3}{*}{$\mathrm{Ni1.5/A110}$} & 24 & $21 \pm 14$ & $36 \pm 16$ & $55 \pm 24$ \\
\cline { 2 - 5 } & 48 & $16 \pm 9$ & $41 \pm 17$ & $63 \pm 27$ \\
\cline { 2 - 5 } & 72 & $20 \pm 14$ & $47 \pm 28$ & $71 \pm 38$ \\
\hline
\end{tabular}

A

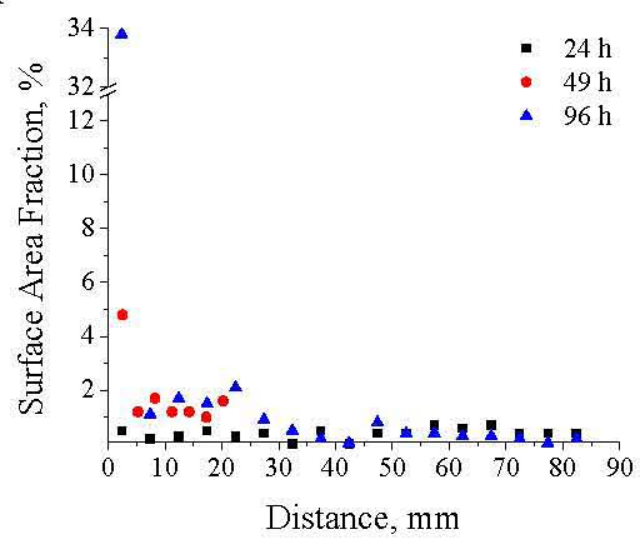

$\mathrm{C}$
B

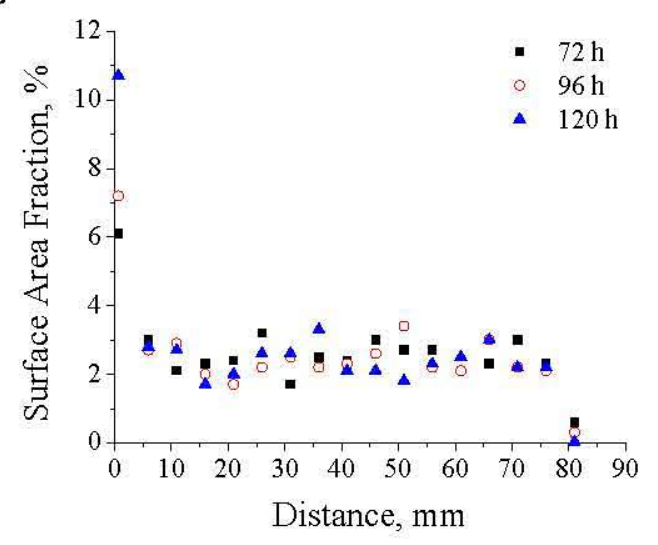

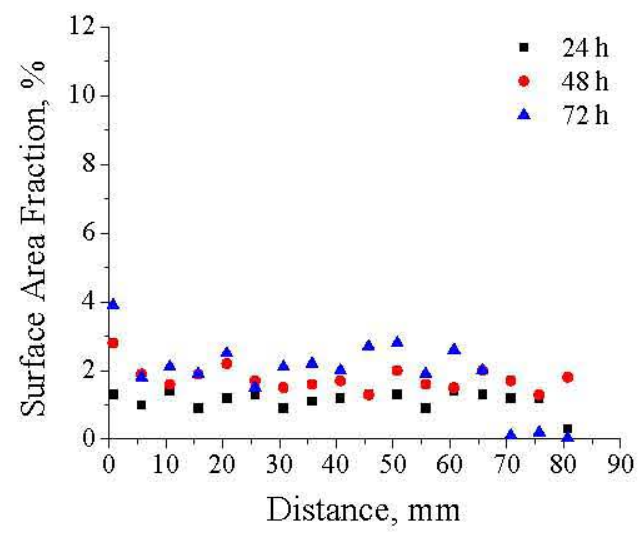

Figure 3. Surface area fraction in \% occupied by the particles for Ni1.5/Fe17.5 (A),

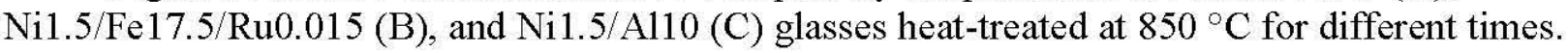


B

A
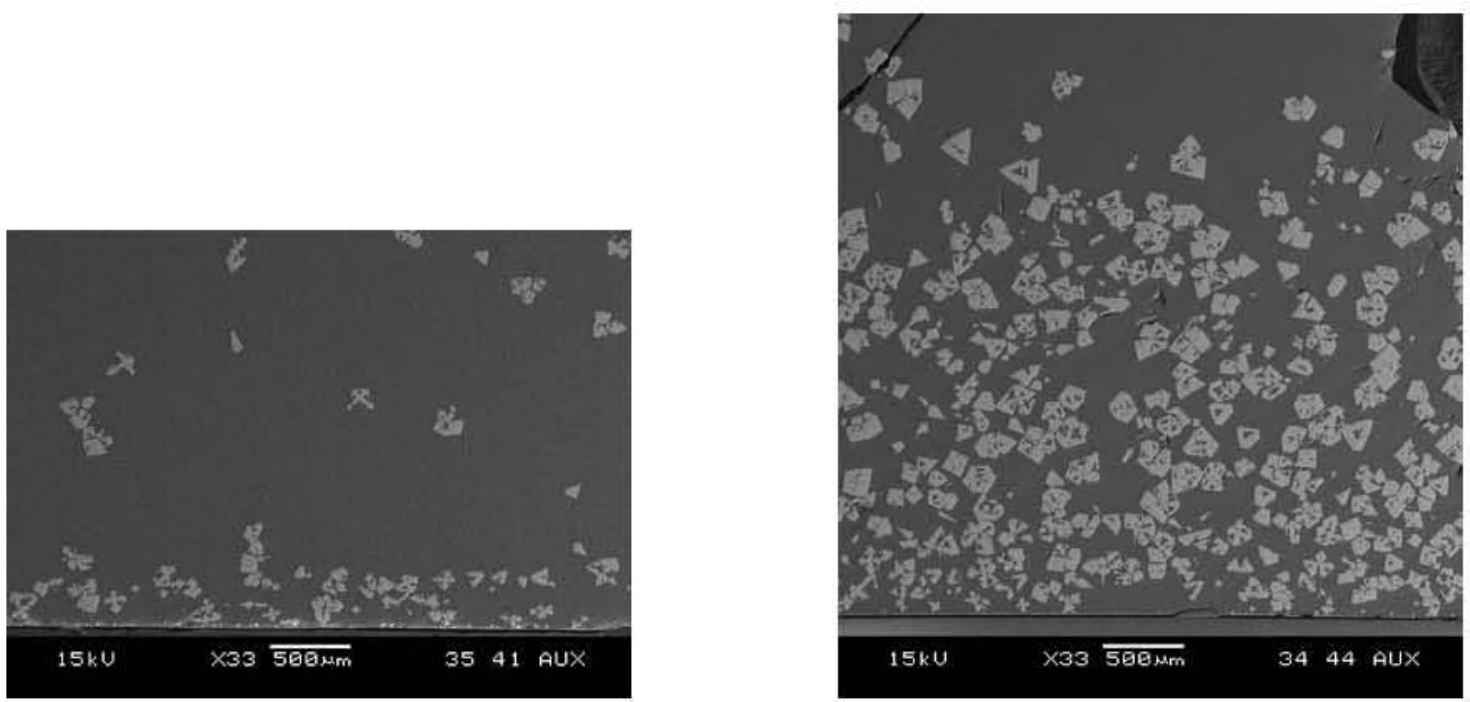

Figure 4. SEM images of accumulated layers for Ni1.5/Fe17.5 glass heat-treated at $850^{\circ} \mathrm{C}$ for $49 \mathrm{~h}(\mathrm{~A}, 469 \mu \mathrm{m})$ and $96 \mathrm{~h}(\mathrm{~B}, 3111 \mu \mathrm{m})$.

A

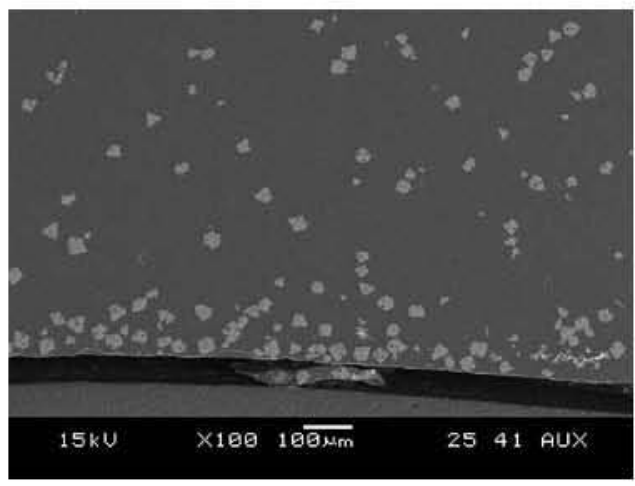

$\mathrm{B}$

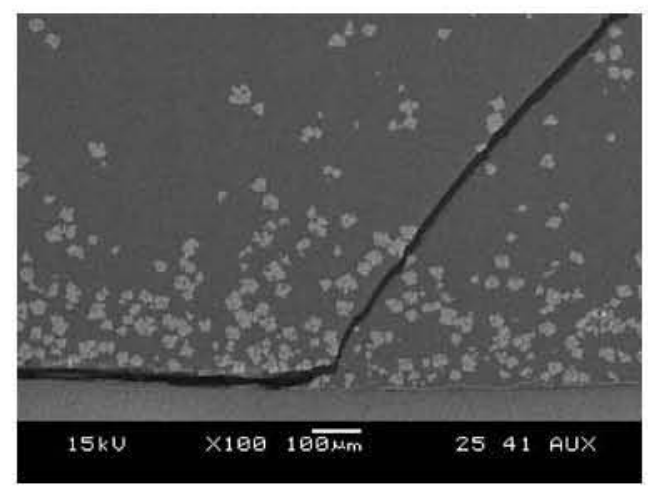

Figure 5. SEM images of accumulated layers for Ni1.5/Fe17.5/Ru0.015 glass heat-treated at $850^{\circ} \mathrm{C}$ for $72 \mathrm{~h}(\mathrm{~A}, 79 \mu \mathrm{m})$ and $120 \mathrm{~h}(\mathrm{C}, 168 \mu \mathrm{m})$.

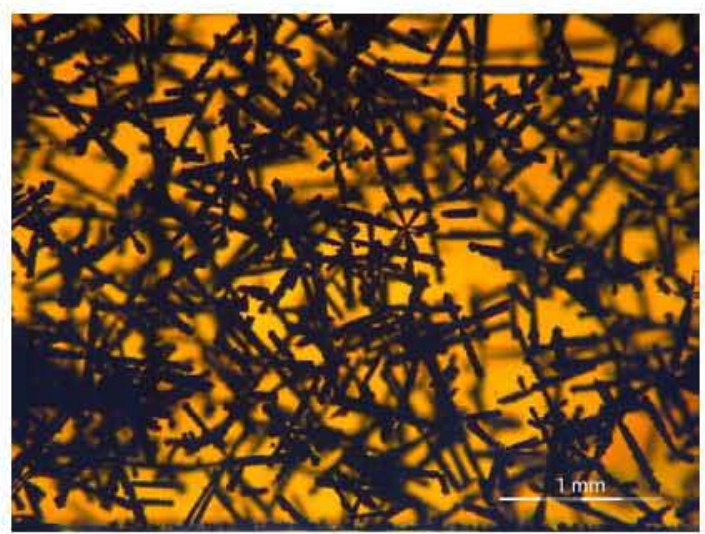

Figure 6. Optical image of spinel dendrite network at the bottom of crucible for Ni1.5/Al10 glass heat-treated at $850^{\circ} \mathrm{C}$ for $72 \mathrm{~h}$. 
A



$\mathrm{B}$



Figure 7. SEM images of dendrites in a 2D plane for Ni1.5/Al10 glass heat-treated at $850^{\circ} \mathrm{C}$ for $24 \mathrm{~h}(\mathrm{~A})$ and $72 \mathrm{~h}(\mathrm{~B})$. The surface area fraction of dendrites increased with time.

Figure 8 shows an elemental dot map for Ni1.5/Fe17.5/Ru0.015 glass heat-treated at $850^{\circ} \mathrm{C}$ for $96 \mathrm{~h}$. Glasses containing high concentration of $\mathrm{Ni}$ and $\mathrm{Fe}$, and some noble metals precipitated spinel crystals with a layer enriched with $\mathrm{Cr}$ and $\mathrm{Na}$. Chromium is partitioned in the glass as $\mathrm{Cr}^{3+}$ and $\mathrm{Cr}^{6+}$ in an approximately 50:50 ratio. ${ }^{6}$ Since some $\mathrm{Cr}^{3+}$ is used for spinel crystals there is an extra $\mathrm{Cr}^{6+}$ that can wet the crystals and form $\mathrm{NaCrO}_{4}$ layer. To test this hypothesis, a several higher magnification line scans were made to determine the changes in composition across the crystals. Figure 9 shows a location of line scan through a selected crystal containing a $\mathrm{RhO}_{2}$ particle. Figures $10 \mathrm{~A}$ and $\mathrm{B}$ visualize changes in the concentration of $\mathrm{Na}, \mathrm{Cr}$, $\mathrm{Rh}, \mathrm{Fe}, \mathrm{Ni}$, and $\mathrm{Mn}$ along this line scan. The line scans revealed that higher concentration of $\mathrm{Na}$ in the skin of crystals is an artifact from charging but $\mathrm{Cr}$ enrichment in $\sim 2.5-\mu \mathrm{m}$ layer was real. This was confirmed by higher average concentration of $\mathrm{Cr}$ in the crystals that formed/grew in Ni1.5/Fe17.5/Ru0.015 glass. Table III shows an elemental composition of spinel crystals in the Ni1.5/Fe17.5, Ni1.5/Fe17.5/Ru0.015, and Ni1.5/Al10 glasses heat-treated at $850{ }^{\circ} \mathrm{C}$ at different times.


Figure 8. Elemental dot map for Ni1.5/Fe17.5/Ru0.015 glass heat-treated at $850^{\circ} \mathrm{C}$ for $96 \mathrm{~h}$. 


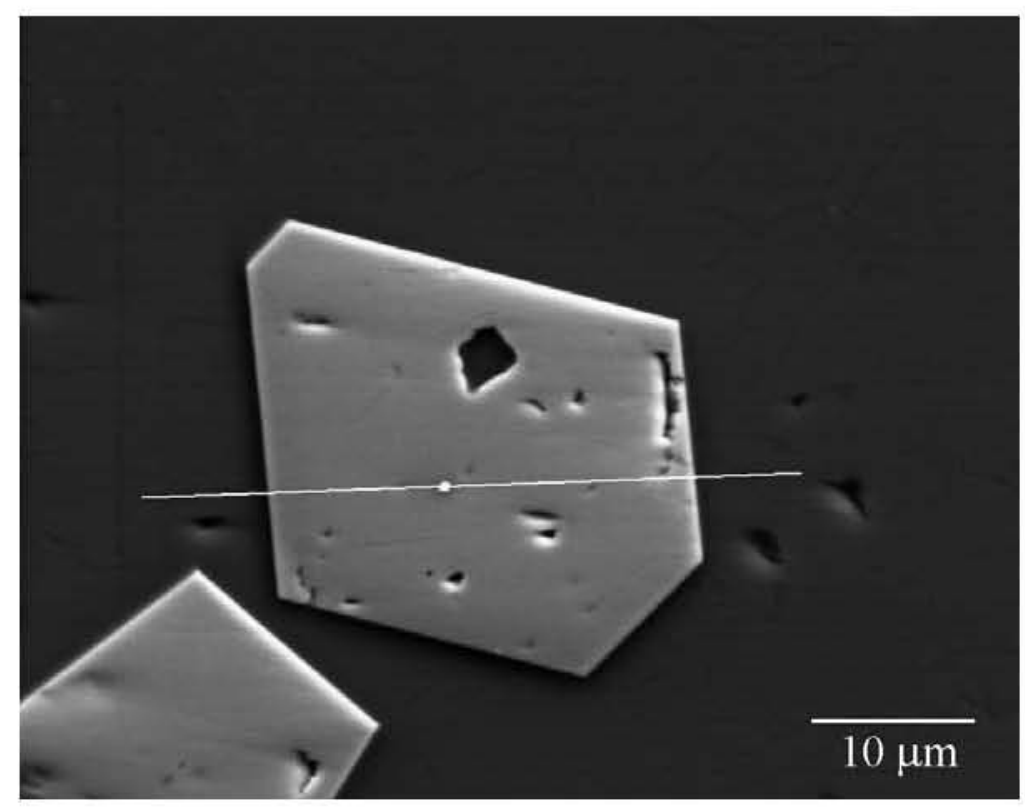

Figure 9. Location of line scan through a spinel crystal that formed in the Ni1.5/Fe17.5/Ru0.015 glass after $72 \mathrm{~h}$ at $850^{\circ} \mathrm{C}$.

A

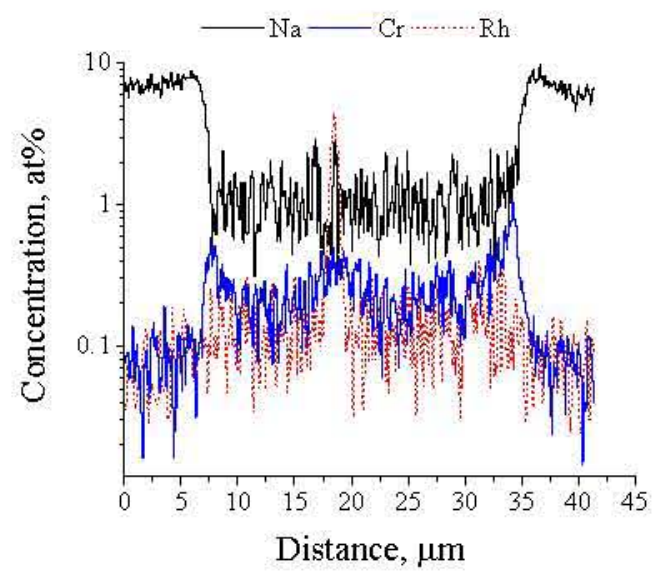

B

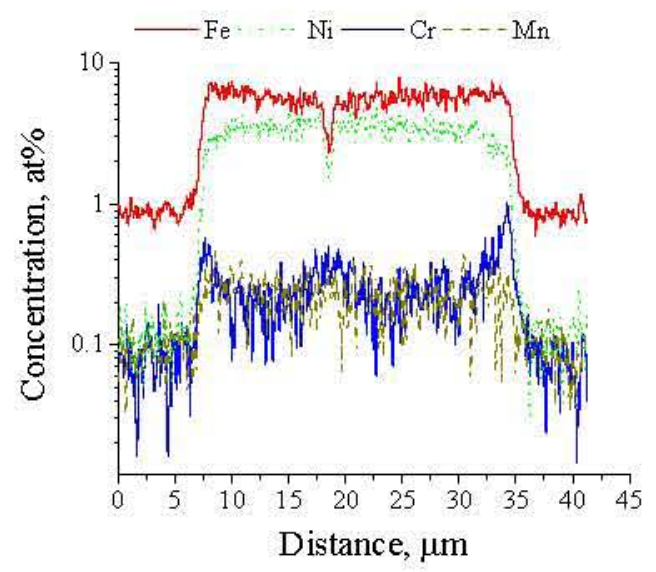

Figure 10. Concentration profiles of $\mathrm{Na}, \mathrm{Cr}$, and $\mathrm{Rh}(\mathrm{A})$, and $\mathrm{Fe}, \mathrm{Ni}, \mathrm{Cr}$, and $\mathrm{Mn}$ (B) along the line scan in Figure 9.

Table III. Composition of spinel crystals in atomic $\%$ for Ni1.5/Fe17.5, Ni1.5/Fe17.5/Ru0.015, and Ni1.5/Al10 glasses heat-treated at $850^{\circ} \mathrm{C}$ at different times.

\begin{tabular}{|c|c|c|c|c|c|}
\hline Glass & $\mathrm{O}$ & $\mathrm{Cr}$ & $\mathrm{Mn}$ & $\mathrm{Fe}$ & $\mathrm{Ni}$ \\
\hline $\mathrm{Ni1} .5 / \mathrm{Fe} 17.5-850^{\circ} \mathrm{C}-49 \mathrm{~h}$ & 81.37 & 0.17 & 0.11 & 11.32 & 7.02 \\
\hline $\mathrm{Ni1} .5 / \mathrm{Fe} 17.5 / \mathrm{Ru} 0.015-850^{\circ} \mathrm{C}-96 \mathrm{~h}$ & 81.22 & 0.42 & 0.15 & 11.45 & 6.75 \\
\hline Ni1.5/Al10-850 ${ }^{\circ} \mathrm{C}-48 \mathrm{~h}$ & 82.26 & 0.35 & 0.11 & 10.79 & 6.49 \\
\hline
\end{tabular}




\section{CONCLUSION}

The experimental study of spinel accumulation indicated that high concentrations of spinel-forming constituents in the glass can produce settling layers of a few mm thick in a few days. Adding $\sim 0.9 \mathrm{wt} \%$ of $\mathrm{NiO}$ and $\sim 3.4 \mathrm{wt} \%$ of $\mathrm{Fe}_{2} \mathrm{O}_{3}$ to baseline glass resulted in the formation of large particles/agglomerates that got bigger over the time to an average size of $\sim 185 \pm 155 \mu \mathrm{m}$, and produced $>3 \mathrm{~mm}$ thick layer after $120 \mathrm{~h}$ at $850^{\circ} \mathrm{C}$. The accumulation of these layers can be significantly suppressed by noble metals $\left(\mathrm{RuO}_{2}, \mathrm{RhO}_{2}\right)$. These components slowed down or stopped the spinel accumulation because of their effect on decreasing the average crystal size. Adding $\sim 0.015 \mathrm{wt} \%$ of $\mathrm{RuO}_{2}$ to high-Ni-Fe glass decreased the crystal size and prevented agglomeration of particles. This resulted in the layer less than $0.2 \mathrm{~mm}$ thick after $120 \mathrm{~h}$ at $850{ }^{\circ} \mathrm{C}$. Adding of $\sim 1.8 \mathrm{wt} \% \mathrm{Al}_{2} \mathrm{O}_{3}$ to high-Ni glass resulted in the formation of a network of spinel dendrites that prevented accumulation of particles into a compact spinel layer. There is a reasonable chance that the spinel crystals locked in this non-compacted layer can be removed with glass during the pouring into canisters. X-ray tomography proved to be a useful non-destructive technique to evaluate an agglomeration of large particles and to provide a spatial distribution of particles in the relatively large glass volumes.

\section{ACKNOWLEDGEMENT}

The authors are grateful to Jarrod Crum for help with collection of elemental dot maps and the U.S. Department of Energy's Hanford Tank Waste Treatment and Immobilization Plant Federal Project Office, Engineering Division, for financial support. Pacific Northwest National Laboratory is operated by Battelle for the U.S. Department of Energy under Contract DE-AC0576RL01830.

\section{REFERENCES}

${ }^{1}$ M.E. Smith, D.F. Bickford, The behavior and effects of the noble metals in the DWPF melter system, WSRC-TR-97-00370, Aiken, SC, March 1998.

${ }^{2}$ N.D. Hutson, D.C. Witt, D.F. Bickford, S.K. Sundaram, On the issue of noble metals in the DWPF melter, WSRC-TR-2001-00337, Aiken, AC, August 2001.

${ }^{3}$ J. Matyáš, J.D. Vienna, A. Kimura, M. Schaible, and R.M.Tate, Development of CrystalTolerant Waste Glasses, Ceramic Transactions 222, 41-51 (2010).

${ }^{4}$ K. M. Fox, D. K. Peeler, T. B. Edwards, D. R. Best, I. A. Reamer, R. J. Workman, J. C. Marra, B. J. Riley, J. D. Vienna, J. V. Crum, J. Matyáš, A. B. Edmondson, J. B. Lang, N. M. Ibarra, A. Fluegel, A. Aloy, A. V. Trofimenko, and R. Soshnikov, International Study of Aluminum Impacts on Crystallization in U.S. High Level Waste Glass, , Savannah River National Laboratory, Aiken, South Carolina, SRNS-STI-2008-00057 (2008).

${ }^{5}$ J. Matyáš, A.R. Huckleberry, C.P. Rodriguez, J.B. Lang, A.T. Owen, and A.A. Kruger, HLW Glass Studies: Development of Crystal-Tolerant HLW Glasses, PNNL-21308 (2012).

${ }^{6}$ H. D. Schreiber, B.K. Kochanowski, C.W. Schreiber, A.B. Morgan, M.T. Coolbaugh, and T.G. Dunlap, Compositional dependence of redox equilibria in sodium silicate glasses, $J$. Non-Cryst. Solids 177, 340-346 (1994). 